\title{
Uptake of Vibrio anguillarum bacterin in the posterior intestine of rainbow trout Oncorhynchus mykiss, sea bass Dicentrarchus labrax and turbot Scophthalmus maximus after oral administration or anal intubation
}

\author{
M. Vigneulle, F. Baudin Laurencin \\ Centre National d'Etudes Vétérinaires et Alimentaires - CNEVA, Laboratoire de Pathologie des Animaux Aquatiques, BP 70 , \\ F-29280 Plouzane, France
}

\begin{abstract}
The intestinal uptake of Vibrio anguillarum bacterin was studied in rainbow trout Oncorhynchus mykiss (Richardson) sea bass Dicentrarchus labrax (L.) and turbot Scophthalmus maximus (L.) using 2 delivery methods: oral administration (OA) and anal intubation (AI). At selected time intervals after antigen administration (from Day 1 to Day 21) fish were killed and sectioned for histology. The location of the bacterin was determined by staining intestinal, kidney, and spleen sections using the indirect fluorescent antibody technique. Antigen uptake was observed only in the posterior intestine of the vaccinated fish; antigen was never detected in the anterior kidney and spleen sections. The Vibrio bacterin was detected in the lamina epithelialis for up to $21 \mathrm{~d}$ following delivery. After AI the fluorescence was stronger than after $O A$ regardless of species. Some differences in the bacterin uptake occurred among the fish species. The implications of these differences are discussed.
\end{abstract}

\section{INTRODUCTION}

Vibriosis, a widely distributed bacterial haemorrhagic septicaemia of fish, is caused in France by Vibrio anguillarum (Baudin Laurencin 1981). Numerous wild and reared fish species are susceptible to this disease and in French fish farms the following species are often affected: rainbow trout Oncorhynchus mykiss (Richardson), sea bass Dicentrarchus labrax L. and turbot Scophthalmus maximus L.

To date, vaccination of fish by intraperitoneal injection, bath immersion or spraying has proved to be successful. However, although oral delivery of vaccines has generally been considered the most suitable method of mass vaccination for fish of all sizes, oral vaccines are not yet commercially available. Injection confers the best protection, followed by immersion, and finally oral delivery (Evelyn \& Ketcheson 1980, Tangtrongpiros 1980, Amend \& Johnson 1981, Evelyn 1984).

In marine fish species, good protection has been observed following oral immunization of turbot (Baudin Laurencin \& Batellier 1986) and seabass (Dec et al.
1990). In salmonids, oral immunization has yielded variable results: it resulted in good protection in the studies of Johnson \& Amend (1983) and Vigneulle (1990), but it proved ineffective in studies reported by Baudin Laurencin \& Tangtrongpiros (1980) and Horne et al. (1982). These variable results could in part be due to gastric destruction of food-incorporated antigen. Support for such an idea was provided by Johnson \& Amend (1983), who obtained high levels of protection against vibriosis in sockeye salmon $59 \mathrm{~d}$ following single anal intubation of the bacterin - a procedure that permits the antigen to reach the posterior intestine unaltered. The response with anal intubation was better than that obtained after either oral or immersion vaccination.

Mechanisms involved in oral vaccination are not yet fully understood, but several authors have studied the absorption and effects of vaccine delivered via the oral route. In the rosy barb Barbus conchionus, Davina et al. (1982) demonstrated that Vibrio bacterin was absorbed by the epithelial cells of the lower intestine via pinocytosis. The absorption process lasted for up to $6 \mathrm{~d}$ after 
vaccination. Concomitantly, these authors observed an increase in the number of gut intra-epithelial leucocytes (IEL). In orally vaccinated rainbow trout, Nelson et al. (1985) reported that Vibrio antigen was observed in the intestine; however the antigen was not detected in the other organs of the fish. Likewise, Tatner et al. (1984) reported that a formalized preparation of Aeromonas salmonicida was confined almost exclusively to the gut region following gastric intubation of rainbow trout.

In the present study we report on the intestinal uptake of Vibrio anguillarum bacterin in a salmonid, rainbow trout, and 2 marine fish, sea bass and turbot, following oral administration and anal intubation. Possible leucocyte number modifications were also studied after Giemsa staining of intestinal sections.

\section{MATERIALS AND METHODS}

Experimental specimens. Rainbow trout fingerlings (400; mean weight $5 \pm 1 \mathrm{~g}$ ) were maintained in $12^{\circ} \mathrm{C}$ running freshwater. Sea bass (200; mean weight $50 \pm$ $20 \mathrm{~g}$ ) and turbot (200; mean weight $27 \pm 7 \mathrm{~g}$ ) were maintained in $20^{\circ} \mathrm{C}$ filtered and sterilized running seawater.

Fish were fed commercial dry (trout) or semi-moist (sea bass and turbot) pellets before the experiment and during oral vaccination. Fish were starved from $4 \mathrm{~d}$ prior to vaccination until the end of the experiment. They were fed only when an oral vaccine was administered.

Each fish species was equally divided into 4 vaccination groups (including the unvaccinated controls) and the group were kept in separate $200 \mathrm{l}$ tanks.

Vaccination schedules. 'Vibriffa-bain' vaccine (regis tered name, Rhône-Merieux: formalin-killed Vibrio anguillarum 408 suspension, containing about $2 \times 10^{11}$ bacteria $\mathrm{ml}^{-1}$ ) was used in all of the trials.

Anal intubation (AI): An agar solution $(0.4 \%)$ at $45^{\circ} \mathrm{C}$ was added to the bacterin to provide a $1: 10$ dilution of bacterin. This preparation was drawn into sterile syringes to which a flexible catheter tube was affixed (Clay Adams: PE 50, internal diameter (i.d.) $=0.58 \mathrm{~mm}$ for trout; PE 90, i.d. $=0.86 \mathrm{~mm}$ for sea bass and turbot). Fish were anaethetized with 2 phenoxy ethanol at a concentration of $0.2 \mathrm{ml} \mathrm{l}^{-1}$ and rectally intubated with the vaccine preparation. with $0.5 \mathrm{ml}$ for trout, $2 \mathrm{ml}$ for sea bass, and $1 \mathrm{ml}$ for turbot. The catheter was introduced via the anus up to the anterior intestine, and then slowly withdrawn while releasing the vaccine preparation throughout the posterior intestine. The length of the tube to be inserted was previously determined for each species. The amount of bacterin actually delivered was $10^{10}$ bacterial cells (b.c.) for trout, $4 \times 10^{10}$ b.c. for sea bass, and $2 \times 10^{10}$ b.c. for turbot. The controls received the agar solution without bacterin.
Oral administration (OA): The vaccine-containing feed was prepared daily by impregnation of the feed with the 1:10 diluted bacterin $(10 \% \mathrm{w} / \mathrm{w})$. Fish were fed for $5 \mathrm{~d}$ at the usual rate of $3 \%$ (trout) or $4 \%$ (sea bass and turbot) of the body weight per day. At the end of treatment, each individual had ingested approximately $1.5 \times 10^{9}$ b.c. (trout), $2 \times 10^{10}$ b.c. (sea bass), or $1 \times 10^{10}$ b.c. (turbot). Control fish were fed a diet without bacterin, at the same rates.

Sampling. To determine the tissue location of the delivered bacterin, and the tissue and leucocyte response to the treatments, 5 turbot, 5 sea bass and 10 trout were sampled in vaccinated and non-vaccinated groups at $1,2,3,4,7,9,11,14,18$, and $21 \mathrm{~d}$ after $\mathrm{AI}$ or after the beginning of the OA. The fish were sacrificed and the middle part of the posterion intesiine, the spleen, and the anterior kidney were removed for histological studies.

Histology. Tissues were fixed in Bouin's fluid, processed into paraffin wax, and sectioned at 5 um. Histological changes were investigated following Giemsa staining. The IFAI used to determine antigen uptake was a modification of that described by Johnson et al. (1974). After paraffin removal, sections were covered with a 1:10 dilution of rabbit anti-Vibrio 408 serum. Slides were incubated in a moist chamber at $30^{\circ} \mathrm{C}$ for $30 \mathrm{~min}$ and then rinsed with 2 changes of $\mathrm{pH} 7.2$ phosphate-buffered saline (PBS) for $10 \mathrm{~min}$. A 1:20 dilution of a fluorescein-labeled anti-rabbit immunoglobulin was added and the slides were incubated in a moist chamber at $30^{\circ} \mathrm{C}$ for $30 \mathrm{~min}$. The slides were then rinsed with 2 changes of PBS for 10 min. A cover glass was affixed to each section with 'Fluoprep' mounting medium (Biomerieux) and the sections were examined with a Reichert epifluorescence microscope. For a semi-quantitative evaluation of the fluorescence in the lamina epithelialis, fish intestinal section was marked (graded) according to its fluorescent intensity, as follows: 0 , absence of fluorescence; 1 , weak fluorescence; 2 , distinct fluorescence ${ }_{i} 3$, pronounced fluorescence; 4, deep fluorescence. A mean mark (m.m.) and a standard error (SE) were calculated for each sample.

\section{RESULTS}

Antigen, detected on the basis of its specific fluorescence, was observed in the posterior intestine of the vaccinated fish but not in the intestine of the control fish. No fluorescence was detected in anterior kidney or spleen sections from any of the fish species. The proportions $(P)$ of the variously treated fish exhibiting fluorescence in the posterior intestine at any given sampling time are summarized in Table 1. Semi-quantitative evaluation of antigen uptake (fluorescence 
Table 1. Oncorhynchus mykiss, Dicentrarchus labrax and Scophthalmus maximus. Proportions of trout, sea bass and turbot exhibiting intestinal mucosal fluorescence after introduction of Vibrio anguillarum bacterin by oral administration (OA) or anal intubation (Al). Fluorescence was observed in different parts of the intestinal sections, as follows: (GL) gut lumen; (ES) external surface of the epithelium; (BB) brush border of the epithelial cells; (EC) supranuclear area of the epithelial cells; (CC) cells of the subepithelial connective tissue

\begin{tabular}{|c|c|c|c|c|c|c|c|c|c|c|c|c|c|}
\hline \multirow[t]{2}{*}{ Species } & \multirow[t]{2}{*}{ Delivery } & \multirow{2}{*}{$\begin{array}{l}\text { Number of } \\
\text { fish sampled }\end{array}$} & \multirow{2}{*}{$\begin{array}{l}\text { Fluorescence } \\
\text { repartition }\end{array}$} & \multicolumn{10}{|c|}{ Days post vaccination } \\
\hline & & & & 1 & 2 & 3 & 4 & 7 & 9 & 11 & 14 & 18 & 21 \\
\hline \multirow{10}{*}{ Trout } & OA & 10 & $G L$ & 1.0 & 1.0 & 1.0 & 1.0 & 10 & 0 & 0 & 0 & 0 & 0 \\
\hline & & & ES & 0 & 0 & 0.1 & 1.0 & 0 & 0 & 0 & 0 & 0 & 0 \\
\hline & & & $\mathrm{BB}$ & 0 & 0 & 0 & 0.4 & 0.2 & 0 & 0 & 0 & 0 & 0 \\
\hline & & & EC & 0 & 0 & 0 & 0 & 0.7 & 0.6 & 0.8 & 0.9 & 0.2 & 0 \\
\hline & & & $\mathrm{CC}$ & 0 & 0 & 0 & 0 & 0 & 0 & 0 & 0 & 0 & 0 \\
\hline & AI & 10 & $G L$ & 0.9 & 0.3 & 0.1 & 0.5 & 0 & 0 & 0 & 0 & 0 & 0 \\
\hline & & & ES & 0.9 & 0.3 & 0.3 & 0.4 & 0 & 0 & 0 & 0 & 0 & 0 \\
\hline & & & $\mathrm{BB}$ & 0.5 & 0.2 & 0.3 & 0.4 & 0 & 0 & 0 & 0 & 0 & 0 \\
\hline & & & $\mathrm{EC}$ & 0.8 & 0.9 & 0.8 & 0.9 & 1.0 & 0.8 & 1.0 & 0.5 & 0.7 & 0 \\
\hline & & & $\mathrm{CC}$ & 0 & 0 & 0 & 0 & 0 & 0 & 0 & 0 & 0 & 0 \\
\hline \multirow[t]{10}{*}{ Seabass } & $O A$ & 5 & GL & 0.8 & 1.0 & 1.0 & 1.0 & 0 & 0 & 0 & 0 & 0 & 0 \\
\hline & & & ES & 0 & 0 & 0.2 & 0 & 0 & 0 & 0 & 0 & 0 & 0 \\
\hline & & & $\mathrm{BB}$ & 0 & 0 & 0 & 0 & 0 & 0 & 0 & 0 & 0 & 0 \\
\hline & & & $\mathrm{EC}$ & 0.8 & 1.0 & 0.8 & 1.0 & 0.8 & 0.8 & 0.6 & 1.0 & 0 & 0.2 \\
\hline & & & $\mathrm{CC}$ & 0 & 0 & 0 & 0 & 0 & 0 & 0 & 0 & 0 & 0 \\
\hline & $\mathrm{Al}$ & 5 & $\mathrm{GL}$ & 0 & 0 & 0 & 0 & 0 & 0 & 0 & 0 & 0 & 0 \\
\hline & & & ES & 0 & 0 & 0 & 0 & 0 & 0 & 0 & 0 & 0 & 0 \\
\hline & & & $\mathrm{BB}$ & 0 & 0 & 0 & 0 & 0 & 0 & 0 & 0 & 0 & 0 \\
\hline & & & $\mathrm{EC}$ & 0.8 & 0.6 & 1.0 & 0.8 & 1.0 & 0.8 & 0.4 & 0.8 & 0.2 & 0 \\
\hline & & & $\mathrm{CC}$ & 0.4 & 0.4 & 0.4 & 0 & 0.6 & 0.4 & 0.6 & 0.2 & 0.2 & 0.2 \\
\hline \multirow[t]{10}{*}{ Turbot } & $O A$ & 5 & GL & 1.0 & 1.0 & 1.0 & 1.0 & 1.0 & 0 & 0 & 0 & 0 & 0 \\
\hline & & & ES & 1.0 & 1.0 & 1.0 & 1.0 & 1.0 & 1.0 & 1.0 & 1.0 & 1.0 & 1.0 \\
\hline & & & $B B$ & 0 & 0 & 0 & 0 & 0 & 0 & 0 & 0 & 0 & 0 \\
\hline & & & $\mathrm{EC}$ & 1.0 & 1.0 & 1.0 & 1.0 & 1.0 & 1.0 & 1.0 & 1.0 & 1.0 & 1.0 \\
\hline & & & $\mathrm{CC}$ & 0 & 0 & 0 & 0 & 0 & 0 & 0 & 0 & 0 & 0 \\
\hline & AI & 5 & GL & 0 & 0 & 0 & 0 & 0 & 0 & 0 & 0 & 0 & 0 \\
\hline & & & ES & 1.0 & 1.0 & 1.0 & 1.0 & 1.0 & 1.0 & 1.0 & 1.0 & 1.0 & 1.0 \\
\hline & & & $\mathrm{BB}$ & 0 & 0 & 0 & 0 & 0 & 0 & 0 & 0 & 0 & 0 \\
\hline & & & EC & 1.0 & 1.0 & 1.0 & 1.0 & 1.0 & 1.0 & 1.0 & 1.0 & 1.0 & 1.0 \\
\hline & & & $\mathrm{CC}$ & 0 & 0 & 0 & 0 & 0 & 0.4 & 0.2 & 0.6 & 0 & 0.4 \\
\hline
\end{tabular}

m.m.) in the lamina epithelialis after OA and AI are illustrated in Figs. 1 \& 2, respectively.

\section{Differences between $\mathrm{OA}$ and $\mathrm{AI}$}

Following OA, fluorescence was present in the intestinal lumen from Day 1 to Day 7 in trout and turbot, and from Day 1 to Day 4, in sea bass. After AI, the intestinal lumen displayed some fluorescence from Day 1 to Day 4 , in trout, but no fluorescence was observed in turbot and sea bass. The lamina epithelialis of trout exhibited fluorescence only from Day 7 to Day 18 following $O A$; in contrast, such fluorescence was observed from Day 1 after AI.

Fluorescence was always more pronounced after Al than after OA, regardless of the fish species. After AI, a few fluorescent host cells were present within the subepithelial connective tissue of some intestinal sections ( 1 to 3 fish per sampling day per species), from Day 1 to Day 21 in sea bass and from Day 9 to Day 21 in turbot.

\section{Interspecies comparison}

Fluorescent bacterin was observed on the external surface of the intestinal epithelium from Day 1 to Day 4 in trout, from Day 1 to Day 21 in turbot, and only on Day 3, after OA, in sea bass. The brush border was fluorescent (from Day 1 to Day 7) in trout only. The location of the fluorescent bacterin in the intestinal mucosa differed according to fish species. In sea bass, a continuous fluorescent deposit was observed in the epithelial cells of the entire mucosal fold. In contrast, 


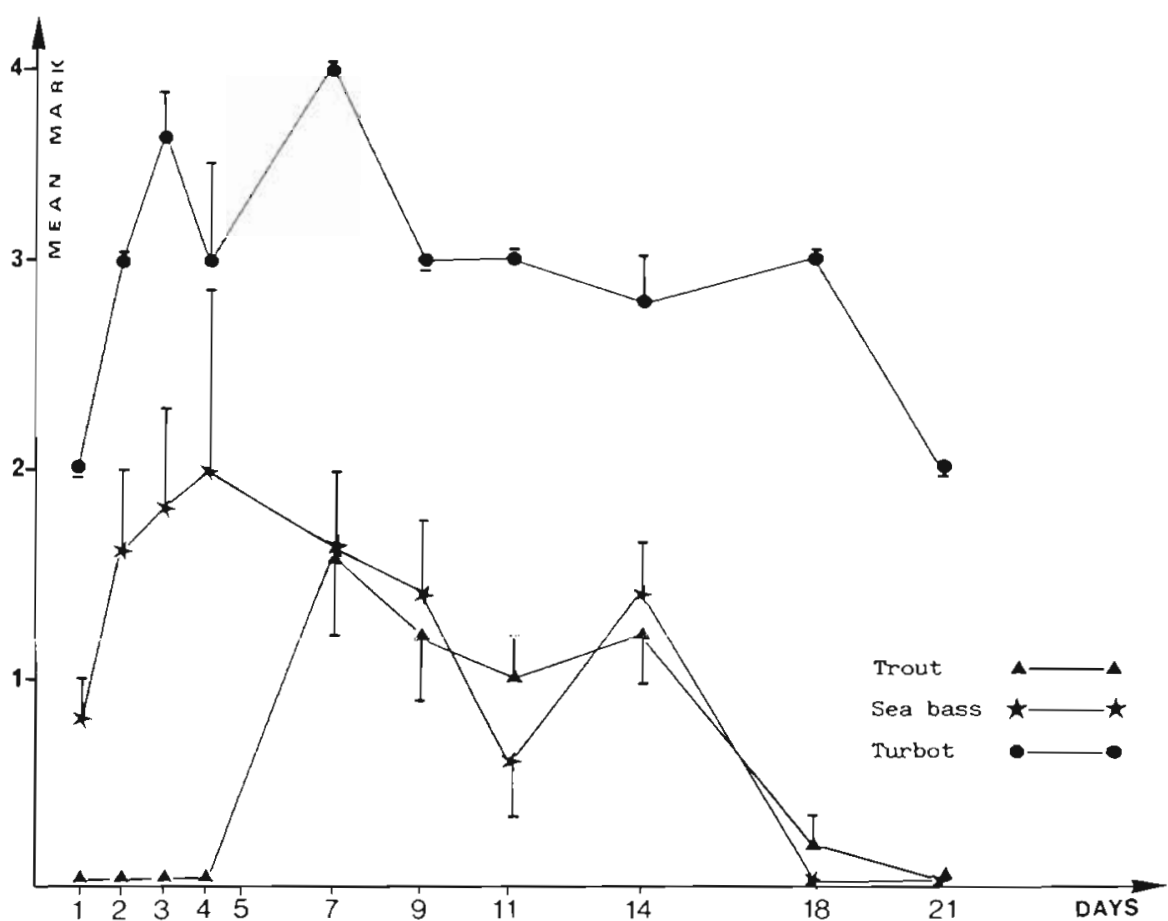

$4+44$

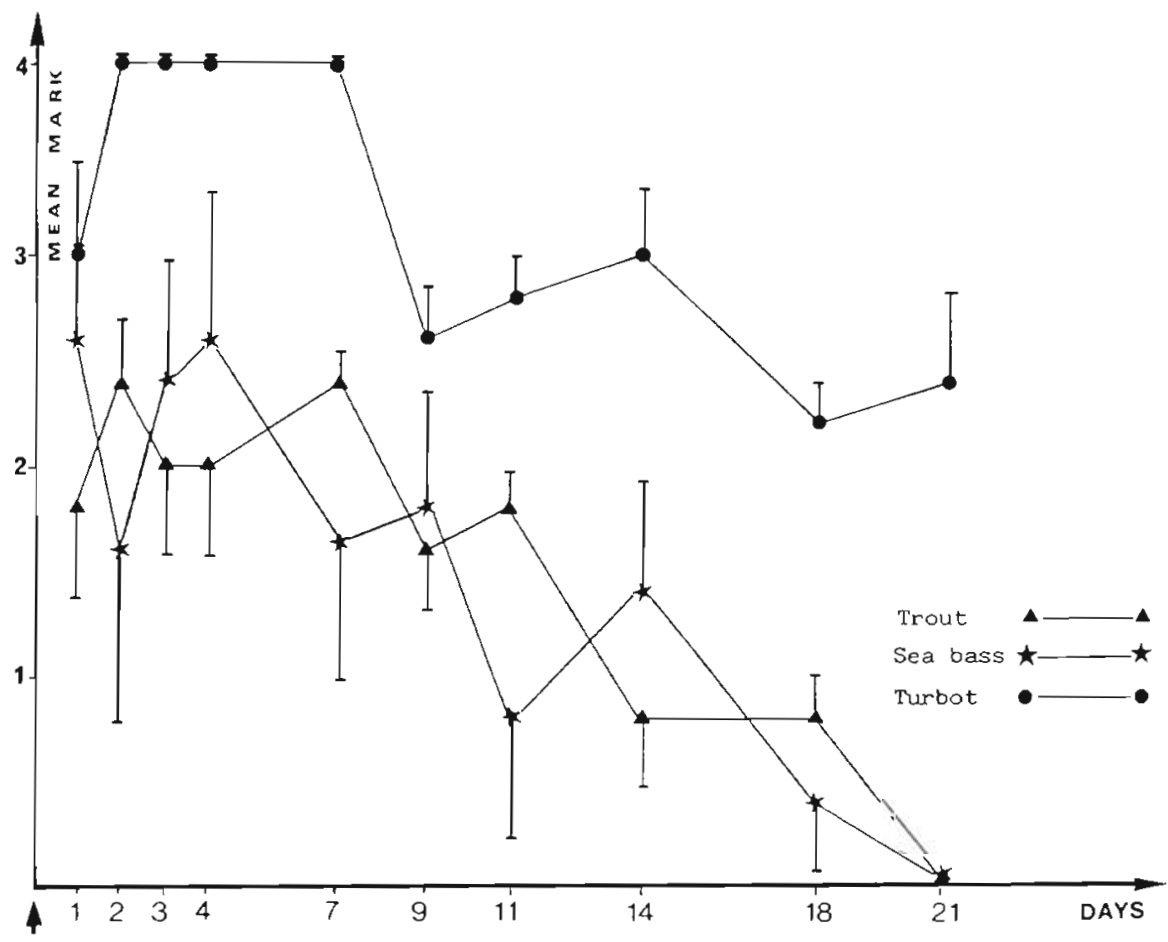

Fig. 1. Oncorhynchus mykiss, Dicentrarchus labrax and Scophthalmus maximus. Semi-quantitative evaluation of fluorescent Vibrio anguillarum bacterin in the lamina epithelialis of sea bass, turbot and trout after oral vaccination. Data expressed as means \pm SE from 5 sea bass, 5 turbot and 10 trout. Arrows indicate days of oral administration; mean mark values are $(0)$ absence of fluorescence, (1) weak fluorescence, (2) distinct fluorescence, (3) pronounced fluorescence, (4) deep fluorescence
Fig. 2. Oncorhynchus mykiss, Dicentrarchus labrax and Scophthalmus maximus. Semi-quantitative evaluation of fluorescent Vibrio anguillarum bacterin in the lamina epithelialis of sea bass, turbot and trout after anal intubation. Data expressed as means \pm SE from 5 sea bass, 5 turbot and 10 trout. Arrow indicates day of oral administration; mean mark values as in Fig. 1 this fluorescence was generally restricted to the upper part of the folds in turbot and was limited to a small portion of the folds in trout (Figs. 3 to 5).

In turbot, bacterin absorption in the lamina epithelialis appeared more prominent than in the other species. Whatever the vaccination route, antigen was observed in all turbot sampled from Day 1 to Day 21. Maximum absorption m.m. (= 4) was reached in the first week after OA or AI. Subsequent disappearance of antigen in turbot was protracted, and the m.m. was still 
Fig. 3. Oncorhynchus mykiss. Mucosal folds of trout lower intestine, exhibiting accumulation of Vibrio anguillarum bacterin (arrows) $24 \mathrm{~h}$ post anal intubation of the antigen. Scale bar $=50 \mu \mathrm{m}$

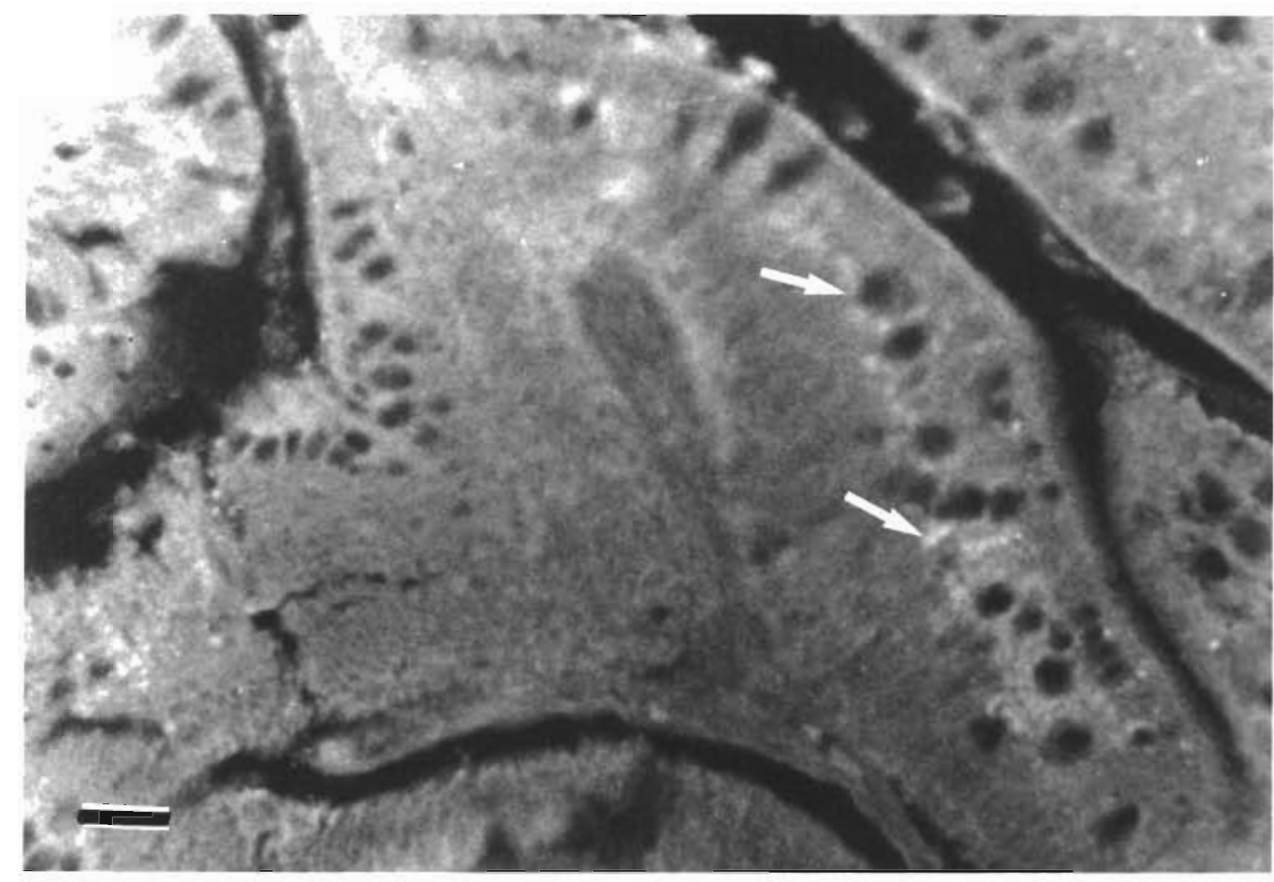

Fig. 4. Dicentrarchus labrax. Mucosal folds of sea bass lower intestine, exhibiting accumulation of Vibrio anguillarum bacterin (arrows) $24 \mathrm{~h}$ post anal intubation of the antigen. Scale bar $=50 \mu \mathrm{m}$

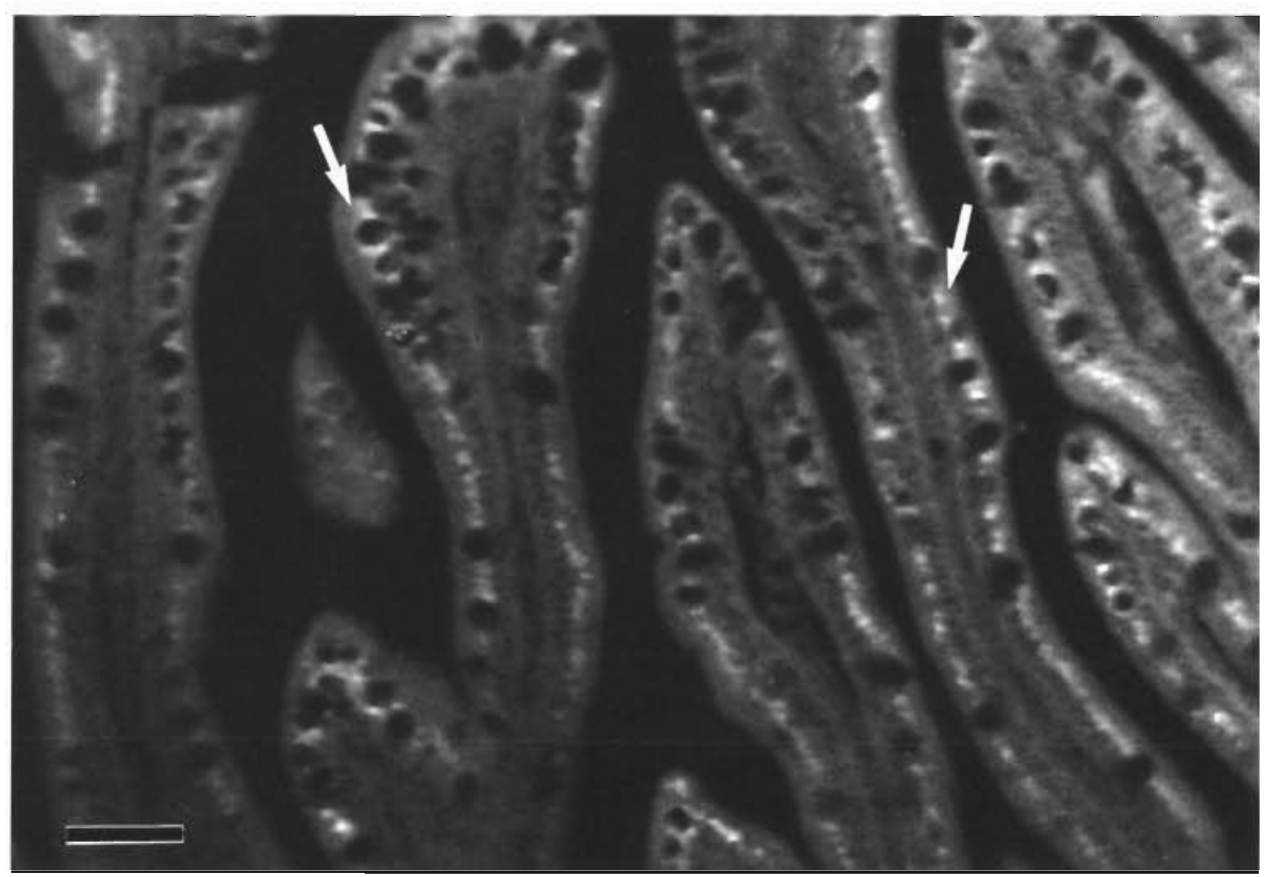

$\geqslant 2$ for each of the delivery routes even after $21 \mathrm{~d}$. In trout and sea bass, intestinal antigen uptake followed a similar pattern, but after OA, absorption commenced on Day 1 in sea bass $(P=4 / 5, \mathrm{~m} . \mathrm{m} .=0.8 \pm 0.20)$ and on Day 7 in trout $(P=7 / 10, \mathrm{~m} . \mathrm{m} .=1.6 \pm 0.39)$. Depending on the vaccination technique (OA or $\mathrm{Al}$ ), the maximum m.m. values obtained in the first week were $2 \pm 0.89$ or $2.6 \pm 0.87$ for sea bass and $1.6 \pm 0.39$ or $2.4 \pm 0.30$ for trout. Thereafter, absorption values decreased values to zero by Day 21 .
No histological differences were observed between vaccinated and control fish, and there were no apparent increases in the leucocyte number of the intestinal mucosa.

\section{DISCUSSION}

The IFAT provided a specific method for detecting the bacterin in fish tissues. However, at best, the technique permitted only a crude estimate of the 


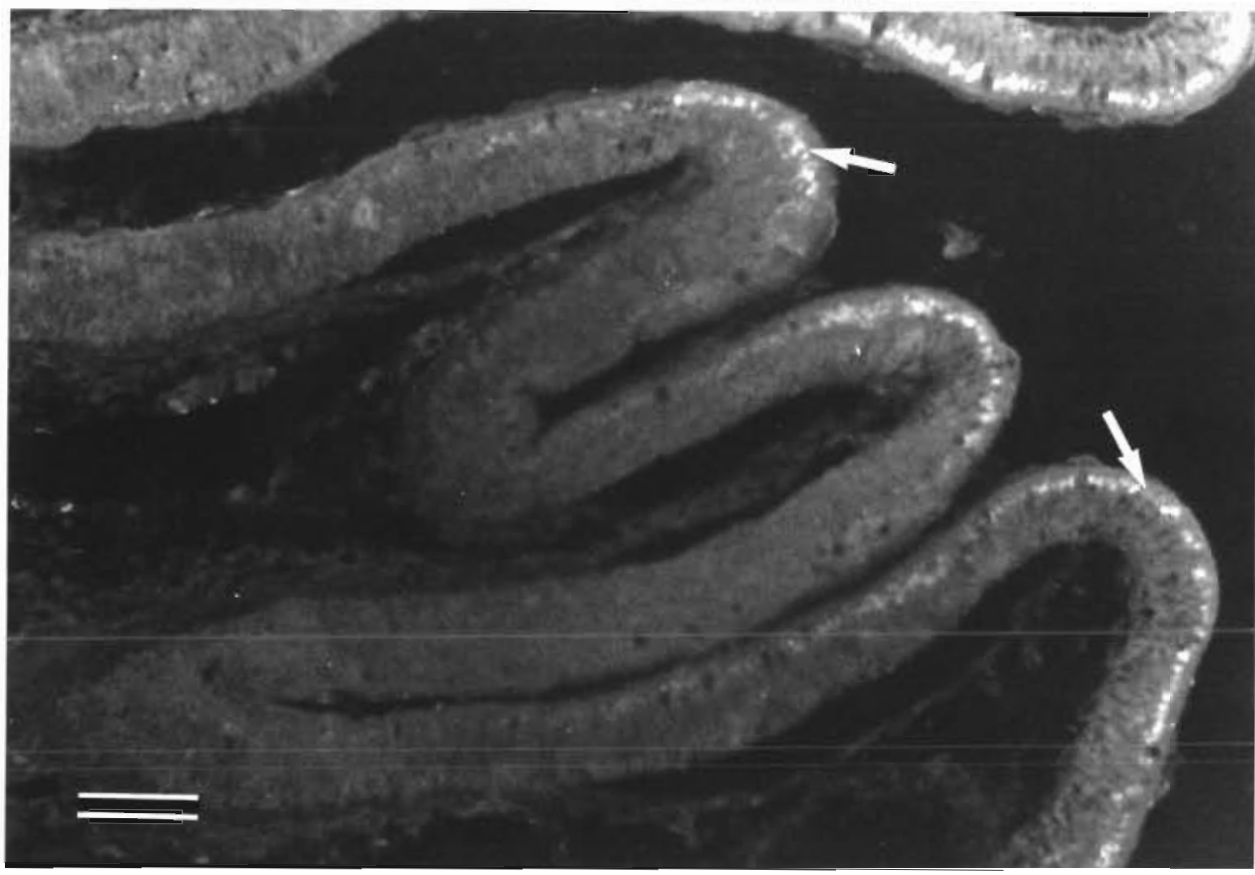

Fig. 5. Scophthalmus maximus Mucosal folds of turbot lower intestine, exhibiting accumulation of Vibrio anguillarum bacterin (arrows) $24 \mathrm{~h}$ post anal intubation of the antigen Scale bar $=50 \mu \mathrm{m}$ amount of antigen taken up and of the surface of the intestine involved in antigen uptake. Moreover, the method was probably too insensitive to visualize small amounts of fluorescence created by single or partially disrupted bacterial cells. In addition, only a small part of each organ was investigated. Nevertheless, the intestinal uptake of Vibrio anguillarum bacterin could be visualized for extended periods of time and gross comparisons between oral and anal delivery techniques and between the 3 fish species were possible.

Studies on antigen uptake in the intestine of fish have generally been undertaken for only short periods of time (for usually less than a week). A preliminary study (Vigneulle unpubl.) showed that with AI, Vibrio anguillarum bacterin uptake was detected by 6 h post administration and was usually evident by $24 \mathrm{~h}$ post AI. A similar rapid intestinal absorption of antigen was reported by Rombout et al. (1986) and Davina et al. (1982). In these and other studies, antigen uptake was observed by 2 to 6 d post delivery, depending on the experimental design (Davina et al. 1982, Tatner et al. 1984, Rombout et al. 1985, Rombout \& Van Den Berg 1989). However, in general, antigen uptake in the intestine has not been studied over longer periods. From the present work the $V$ anguillarum bacterin was still visualized in the lamina epithelialis, albeit with decreasing intensity, 18 to $21 \mathrm{~d}$ after delivery. Nelson et al. (1985) reported that bacterin was observed throughout a $14 \mathrm{~d}$ vaccination period, with maximum presence occurring between Day 5 and Day 7. However, in contrast to the results reported here, the antigen was only detectable for $7 \mathrm{~d}$ after the end of the vaccine feeding. In another study, horseradish peroxidase (HRP) was observed in larval teleosts for up to $15 \mathrm{~d}$ after its administration (Watanabe 1982). The studies of Georgopoulou et al. $(1985,1986 \mathrm{a}, \mathrm{b})$ and those of Rombout et al. (1985) and Rombout \& Van Den Berg (1989) showed that the antigen uptake rate varied with the size of the antigen molecule. Large molecules (a category not very different from bacterial cells) were taken up by pinocytosis and entered large supranuclear vacuoles, where they were ultimately digested.

Intestinal uptake of bacterin, as observed in the present study, was rapid. After AI the fluorescence quickly disappeared from the intestinal lumen and was detectable by Day 1 in the lamina epithelialis. After OA antigen uptake was less rapid, the fluorescence being observed for a longer time in both the lumen and the lamina epithelialis. In addition, the amount of antigen taken up with OA was always less than that taken up with AI and subepithelial fluorescence was observed only with AI. The lesser rate of absorption observed after $O A$ can probably be attributed to the smaller amounts of antigen introduced into the gut lumen. Moreover, depending on the species and perhaps upon the characteristics of the food, only that portion of the bacterin directly in contact with intestinal epithelium is likely to be taken up, the rest being voided with the feces. In addition partial degradation of the antigen in the upper part of the digestive tract may also occur These factors, as well as the feeding strategy, probably explain the differences in protection obtained after 
anal and oral vaccination (cf. Johnson \& Amend 1983, Vigneulle 1990).

Some differences in bacterin uptake were apparent between the 3 fish species studied. In trout the phenomenon seemed to be slower than in the 2 other species. In trout after $\mathrm{AO}$, in spite of a fluorescence in the intestinal lumen, the bacterin was not detectable in the lamina epithelialis until Day 7 ; in contrast, in turbot and sea bass it appeared on Day 1. Also in trout often AI fluorescence was present in the lumen until Day 4; in contrast, in the 2 other species it had disappeared from the lumen of the intestine by Day 1. In trout the uptake seemed to be limited to a small portion of the mucosal folds, and regardless of the delivery route, no fluorescent cells could be observed in the subepithelial connective tissue. In contrast with the results reported here, fluorescence was observed in the subepithelial lamina propria $24 \mathrm{~h}$ after oral intubation of trout with human immunoglobulin G (Georgopoulou \& Vernier 1986). On the whole, intestinal uptake seemed to be less efficient in trout than in turbot and sea bass, which may explain the variable results of oral vaccination trials in trout (Baudin Laurencin \& Tangtrongpiros 1980, Horne et al. 1982). In sea bass, the transit of the bacterin to the intestinal epithelium was rapid, and the fluorescence was distributed along the entire surface of the mucosal folds. This probably explains the rapid passage of the bacterin to the connective tissue in the species and the lesser intensity of the fluorescence in the lamina epithelialis when compared to turbot. Antigen absorption appears to be equally rapid in turbot. In turbot the epithelial fluorescence was always higher than in the other 2 species, probably because all of the uptake occurred at the apex of the mucosal folds. However, in turbot, the constant presence of the bacterin on the external surface of the epithelium (perhaps in the mucus) suggests that there was some limit to epithelial penetration. In sea bass and turbot, the presence of fluorescent cells in the subepithelial connective tissue suggests that a high level of bacterin uptake occurs. This could partly explain the consistent protection obtained in these species following oral vaccination (Baudin Laurencin \& Batellier 1986, Dec et al. 1990). Other factors such as temperature $\left(12\right.$ vs $\left.20^{\circ} \mathrm{C}\right)$ and food (dry vs semi-moist pellets) likely also influence gastric evacuation rates and intestinal transit, and could partly explain the marked species differences in antigen uptake between trout and the 2 other species reported in this study.

In the present study, no modification of the leucocyte population of the intestinal mucosa was observed after vaccination, regardless of fish species or route of vaccine delivery. In contrast, Davina et al. (1982) reported an increase in the intraepithelial leucocyte (IEL) number that lasted for $15 \mathrm{~h}$ after oral intubation. Simi- larly, Rombout \& Van Den Berg (1989) observed an augmentation in the number of intraepithelial macrophages after AI that peaked at $24 \mathrm{~h}$ post AI. These rapid increases in IEL number may have resulted from irritation of the intestinal mucosa by insertion of a tube because it also occurred in the intubated controls. However, Georgopoulou \& Vernier (1986) demonstrated an augmentation between Day 6 and Day 8 of the entire leucocyte population of the posterior intestine after oral intubation of human immunoglubulin G. Moreover, the increase, within this population, of antigen-binding cells and of plaque-forming cells establishes that teleost fish have a local secretory immune system. These results were obtained after enumeration of the isolated intestinal cell population. Thus the methods used in our study may not have been sensitive enough to detect such a temporary augmentation in the number of IEL. Moreover, the first sampling, on Day 1 , may have been too late to detect a possible precocious increase in IEL numbers.

Regardless of the fish species or vaccination method, no fluorescent Vibrio anguillarum bacterin was detectable in other sampled organs (kidney and spleen). However, the presence of fluorescent cells in the intestinal subepithelial connective tissue of sea bass and turbot, after the AI, suggests that some of the antigen likely ended up in the kidney and spleen. Because these fluorescent cells were few, their subsequent presence in the kidney and the spleen would easily have gone undetected by IFAT, especially as only minute sections of each organ were sampled and analysed. The fluorescent subepithelial cells were likely small migrant macrophages, similar to those described by Rombout \& Van Den Berg (1989). Results similar to ours have been reported by Nelson et al. (1985) and by Tatner et al. (1984), who detected the bacterin in the gut but never in other internal organs. On the other hand, Rombout et al. (1985) described ferritin-containing macrophages in the spleen from 3 to $6 \mathrm{~d}$ after the AI of ferritin, indicating that antigen taken up via the gut can be transported to the internal organs. It therefore seems likely that these antigen-laden macrophages could induce a systemic immune response (Rombout et al. 1989). The efficacy of oral and rectal vaccination trials and the protection induced by passive immunization with serum from orally vaccinated fish are supportive for such as systemic immune response (Kawai et al. 1981, Dec et al. 1990, Vigneulle 1990).

Acknowledgements. This work was supported in part by a grant from the Groupement de Coopération Scientifique sur les bases biologiques de l'aquaculture (GCS-BBA). The authors thank A. Le Ven and A. Abiven for their technical assistance. 


\section{LITERATURE CITED}

Amend, D. F., Johnson, K. A. (1981). Current status and future needs of Vibrio anguillarum bacterins Dev. Biol. Standard 49: 403-417

Baudin Laurencin, F. (1981). Fish vibrio strains antisera in France. Symposium on Fish Biologics: serodiagnostics and vaccines. Dev. Biol. Standard 49: 257-259

Baudin Laurencin, F., Batellier, F. (1986). Protection immunitaire du turbot (Scophthalmus maximus) contre la vibriose. In: Vivares, C. P., Bonami, J. R., Jaspers, E. (eds.) Pathology in marine aquaculture. European Aquaculture Society, special publication $N^{\circ} 9 .$, p. 391-403

Baudin Laurencin, F., Tangtrongpiros, J. (1980). Some results of vaccination against vibriosis in Brittany. In: Ahne, W (ed.) Fish disease, 3rd COPRAQ Session. Springer, Heidelberg, p. 60-68

Davina, J. H., Parmentier, H. K., Timmermans, L. P. M. (1982) Effect of oral administration of Vibrio bacterin on the intestine of cyprinid fish. Dev. comp. Immunol. (Suppl.) 2: $157-166$

Dec, C., Angelidis, P., Baudin Laurencin, F. (1990). Effects of oral vaccination against vibriosis in turbot and sea bass. J. Fish Dis. 13: 369-376

Evelyn, T. P. T. (1984). Immunization against pathogenic vibrios. In: de Kinkelin, P., Michel, C. (eds.) Symposium on fish vaccination, Feb. 20-22. O. I. E., Paris, p. 121-150

Evelyn, T P. T., Ketcheson, J. E. (1980). Laboratory and field observations on antivibriosis vaccines. In: Ahne, W. H. (ed.) Fish disease, 3rd COPRAQ Session. Springer, Heidelberg, p. 45-52

Georgopoulou, U., Sire, M. F., Vernier, J. M. (1985). Macromolecular absorption of proteins by epithelial cells of the posterior intestinal segment and their intracellular digestion in the rainbow trout. Ultrastructural and biochemical study. Biol. Cell. 53: 269-282

Georgopoulou, U., Sire, M. F., Vernier, J. M. (1986a). Absorpfion intestinale des protéines sous forme macromoléculaire et leur digestion chez la truite arc-en-ciel. Etude ultrastructurale et biochimique en relation avec la première prise de nourriture. Can. J. Zool. 64: 1231-1240

Georgopoulou, U., Sire, M. F., Vernier, J. M. (1986b). Immunological demonstration of intestinal absorption and digestion of protein macromolecules in the trout (Salmo gairdneri). Cell Tissue Res. 245: 387-395

Georgopoulou, U., Vernier, J. M. (1986). Local immunological response in the posterior intestinal segment of the rainbow trout after oral administration of macromolecules. Dev. comp. Inmunol. 10: 529-537

Responsible Subject Editor: Dr T Evelyn, Nanaimo, B. C. Canada
Horne, M. T., Tatner, M., McDerment, S., Agius, C., Ward, P. (1982). Vaccination of rainbow trout, Salmo gairdneri Richardson, at low temperatures and the long-term persistence of protection. J. Fish Dis. 5: 343-345

Johnson, K. A., Amend, D. F. (1983). Efficacy of Vibrio anguillarum and Yersinia ruckeri bacterins applied by oral and anal intubation of salmonids. J. Fish Dis. 6: 473-476

Johnson G. R., Wobeser, G., Rouse, B. T (1974). Indirect fluorescent antibody technique for detection of RM bacterium of rainbow trout (Salmo gairdneri). J. Fish. Res. Bd Can. 31: 1957-1959

Kawai, K., Kusuda, R., Itami, T. (1981). Mechanisms of protection in ayu vaccinated for vibriosis. Fish Path 15: 257-262

Nelson, J. S., Rohovec, J. S., Fryer, J. L. (1985). Tissue location of Vibrio bacterin delivered by intraperitoneal injection, immersion and oral routes to Salmo gairdneri. Fish Path. 19: $263-269$

Rombout, J. H. W. M., Blok, L. J., Lamers, C. H. J., Egberts, E. (1986). Immunization of carp (Cuprinus carpio) with a Vibrio anguillarum bacterin: indications for a common mucosal immune system. Dev. comp. Immunol. 10: $341-351$

Rombout, J. H. W. M., Lamers, C. H. J., Helfrich, M. H., Dekker, A., Taverne-Thiele, J. J. (1985). Uptake and transport of intact macromolecules in the intestinal epitelium of carp (Cyprinus carpio L.) and the possible immunological implications. Cell Tissue Res. 239: 519-530

Rombout, J. H. W. M., van den Berg, A. A. (1989). Immunological importance of the second gut segment of carp. I. Uptake and processing of antigens by epithelial cells and macrophages. J. Fish Biol. 35: 13-22

Rombout, J. H. W. M, van den Berg, A. A., van den Berg, C. T. G. A., Witte, P., Egberts, E. (1989). Immunological importance of the second gut segment of carp. III. Systemic and/ or mucosal immune responses after immunization with soluble or particulate antigen. J. Fish Biol. 35: 179-186

Tangtrongpiros, J. (1980). La vibriose en Bretagne. Essais de vaccination. Thèse Doct. 3ème cycle, Université de Bretagne occidentale

Tatner, M. F., Johnson, C. M., Horne, M. T. (1984). The tissue localization of Aeromonas salmonicida in rainbow trout, Salmo gairdneri Richardson, following three methods of administration. J. Fish Biol. 25: 95-108

Vigneulle, M. (1990). Yersiniose des salmonidés: étude comparée de différents modes de vaccination. Ichtyophysiologica Acta 13: 43-58

Watanabe, Y (1982). Intracellular digestion of horseradish peroxidase by the intestinal cells of teleosts larvae and juveniles. Bull. Jap. Soc. scient. Fish. 48: 37-42

Manuscript first received: March 16, 1990

Revised version accepted: April 30, 1991 